\title{
Energy Sources and House-Holds Energy Utilization in Melani Rural Community of Eastern Cape, South Africa
}

\author{
Mthimunye Thabiso ${ }^{\# 1}$, Mamphweli Sampson ${ }^{* 2}$, Mukumba Patrick ${ }^{\# 3}$ \\ ${ }^{\text {\# }}$ Physics Department, University Of Fort Hare, Private Bag X1314, Alice, South Africa \\ ${ }^{1}$ Tmthimunye@ufh.ac.za \\ ${ }^{3}$ Pmukumba@ufh.ac.za \\ * Fort Hare Institute Of Technology, Private Bag X1314, Alice, South Africa \\ 22Mamphweli@sun.ac.za
}

\begin{abstract}
A study was conducted in Melani rural community of Nkonkobe district in Eastern Cape province of South Africa, with the aim of identifying types of energy sources and house-holds energy utilization. Melani village $\left(32^{\circ} 43^{\prime} 29^{\prime \prime} \mathrm{S}, 2^{\circ} 07^{\prime} 35^{\prime \prime} \mathrm{E}\right)$ is $20 \mathrm{~km}$ away from Alice town and has a house-hold population of about 350 . The survey was conducted to $50 \%$ of the randomly chosen house-holds using a semi-structured questionnaires and the onset CTA-A hobo current transducers were installed in three house-hold to measure the current used. The survey showed that electricity is the main source of energy for cooking, lighting and heating. While paraffin and candles are used for lighting. The data collected using the data acquisition system has also shown that each house-holds consumes an average of $140 \mathrm{kWh}$ of electricity per month. Assuming this amount of energy being used throughout the year, then on average each house-hold consumes $1680 \mathrm{kWh}$ of electricity per year. The paper concludes that there is a need to promote sustainable energy resources and technologies such as the use of biogas digesters as an alternative source of energy since each house-hold has on average of 20 cattle's and 10 of goats.
\end{abstract}

Keyword - Melani Rural Community, Eastern Cape Province, South Africa, House-Holds, Energy sources

\section{INTRODUCTION}

In South Africa 84\% of house-holds are electrified [1]. The electrified house-holds use the electricity for lighting, cooking or heating. However other sources such as candles, paraffin, firewood and gas continue to be relied upon in non-electrified house-holds. In terms of lighting, house-holds that have been electrified almost exclusively use electricity for lighting purposes (97\%), with a marginal contingent specifying that they continue to rely on candles (1\%) [2]. By contrast, two-thirds of non-electrified house-holds (67\%) rely on candles as the main source of lighting, with paraffin accounting for the predominant energy source for this purpose in most of the remaining cases (26\%) [2]. Other energy sources hardly feature, and no single option is mentioned in more than $5 \%$ of cases.

Cooking represents one of the most energy-intensive applications and it is unsurprising that slightly more than three-quarters (76\%) of house-holds use electricity as the main energy source for cooking [1][2]. The 2011/12 South African Social Attitudes Survey (SASAS) statistics show that only around a tenth (8\%) of electrified house-holds continue to depend on firewood as a main cooking source, with marginal shares reporting gas, solar electricity, paraffin and coal. For non-electrified households, firewood and paraffin predominate as the main energy source for cooking purposes ( $40 \%$ and $50 \%$ respectively). Again, gas, coal, solar electricity and electricity from generators are used in a small percentage of households as the primary source to meet their cooking needs. However, energy crisis in South Africa saw most of the households in rural areas spending $14 \%$ of their total monthly income on energy needs, which is higher than the standardised benchmark of $10 \%$ [1].

Melani rural community of Nkonkobe district is in Eastern Cape. The Melani village (32 $43^{\prime} 29^{\prime \prime}$ S, $27^{\circ} 07^{\prime} 35^{\prime}$ E) is $20 \mathrm{~km}$ away from Alice as the closest town and it has house-hold population of about 350 . Statistic South Africa is also showing that $72 \%$ (Rural) of the population in Nkonkobe municipality are unemployed of $10 \%$ [7].

The aim of this research is identifying types of energy sources and house-holds energy utilization in Melani village Eastern Cape, South Africa. The following were the objectives: To identify sources of energy in Melani village; To identify the sources of energy used by Melani house-holds; To quantify the electrical consumption by the Melani house-holds 


\section{RESEARCH METHODOLOGY}

The study was conducted in Melani village, a village with house-hold population of about 350 . The village is dominated by community members who work at the farms and about $94 \%$ of the population earn below R800 per month [2]. The research was conducted by the administration of a questionnaire that was balanced between open-ended and close-ended types of questions. This was done to obtain relevant data that allows flexibility to meet the intended objectives and, at the same time, not restricting respondents to the given options. Figure 1 shows the photo of the current transducer used for measurement of energy. Questionnaires were administered to 175 randomly selected house-holds and the onset CTA-A hobo current transducers were installed in three randomly chosen house-holds to measure the energy consumption.

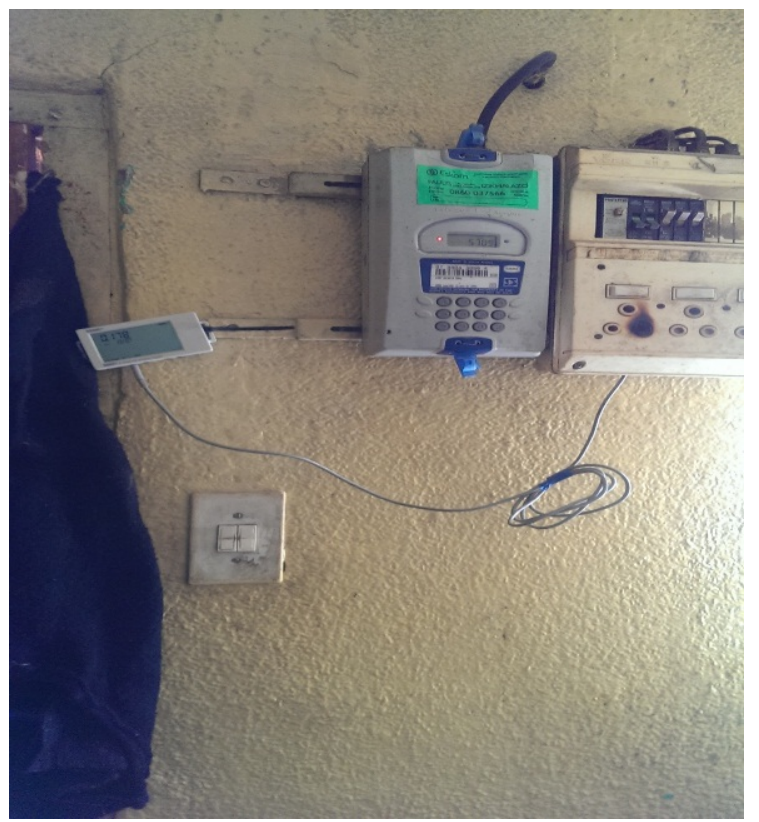

Figure1: CTA-A hobo current transducer connected to Eskom meter box

\section{RESULTS}

\section{A. Survey Results}

The majority of people in Melani village are unemployed, with low literacy level. Most of the house-holds are dependent on pension funds, government grants and subsistence farming.

The house-holds rely on a number of fuels for cooking and lighting, and the quality of Life data disaggregates these fuels into eight: electricity, gas/liquefied petroleum gas (LPG), paraffin, wood, coal, dung, solar energy, and other [3]. Table 1 is showing that the Melani village house-holds rely mostly on Eskom's electricity s their main source of energy mainly for cooking and lighting purposes. Meanwhile few households use paraffin, candles, fire woods and gas as an alternative source of energy.

Each household is made up of at least five members. Table 1 and Table 2 shows a summary of the surveyed households using a single type and multiple types of energy as a source for various purposes.

Table 1: House-holds using single energies as sources.

\begin{tabular}{|c|c|c|c|}
\hline & \multicolumn{3}{|c|}{ Number of house-holds using the energy for the purpose of } \\
\hline Single energy source & Lighting & Cooking & Cooking\& Lighting \\
\hline Electricity & 5 & 0 & 138 \\
\hline Candles & 2 & 0 & 0 \\
\hline Woods & 0 & 3 & 0 \\
\hline Paraffin & 2 & 5 & 3 \\
\hline Gas & 0 & 5 & 0 \\
\hline Total & $\mathbf{9}$ & $\mathbf{1 3}$ & $\mathbf{1 4 1}$ \\
\hline
\end{tabular}

Table 1, shows that 141 house-hold in Melani village are using electricity as their main source of energy for cooking and lighting. While, 13 house-hold is using energy sources like woods, paraffin and gas for cooking purpose only and 9 house-holds use electricity, candles and paraffin for the purpose of lighting only. Table 2 shows the number of house-hold using multiple energies as the source. 
Table 2: House-hold using single energies as sources

\begin{tabular}{|c|c|c|c|}
\hline Multiple energy source & Lighting & Cooking & Cooking\& Lighting \\
\hline Electricity\& Candles & 0 & 0 & 0 \\
\hline Electricity\& Woods & 0 & 3 & 0 \\
\hline Electricity\& Paraffin & 0 & 0 & 2 \\
\hline Electricity\& Gas & 0 & 2 & 0 \\
\hline Candles \& Wood & 0 & 0 & 0 \\
\hline Candles \& Paraffin & 2 & 0 & 0 \\
\hline Candles,Paraffin\& Electricity & 0 & 0 & 0 \\
\hline Gas, Candles \&Electricity & 1 & 0 & 0 \\
\hline Paraffin, Gas\& Electricity & 0 & 2 & 0 \\
\hline Electricity\& Candles & 0 & 0 & $\mathbf{2}$ \\
\hline Total & $\mathbf{3}$ & $\mathbf{7}$ & 0 \\
\hline
\end{tabular}

Table 2, show that 7 house-hold in Melani village are using electricity and woods for cooking purposes as multiple sources of energy. However, 5 other house-hold have indicated that they use other energy sources to either light or both lighting and cooking.

Observing at household energy sources, it is evident that considerable arrays of difference exist between electrified and non-electrified households in the range of energy sources that they employ to meet their basic needs. Those with electricity all reported that they used this source either for lighting, cooking or heating, nevertheless it is apparent that other sources such as candles, paraffin, firewood and gas continue to be relied upon in Melani village. Conversely, in the absence of a domestic connection, non-electrified households rely primarily on candles, paraffin and firewood, with more nominal shares reporting the use of coal and gas. The use of dry cell and car batteries, a solar system, or generator hardly features for electrified and non-electrified households. Figure 2, shows a bar graph of energy usage in percentage for lighting purposes.

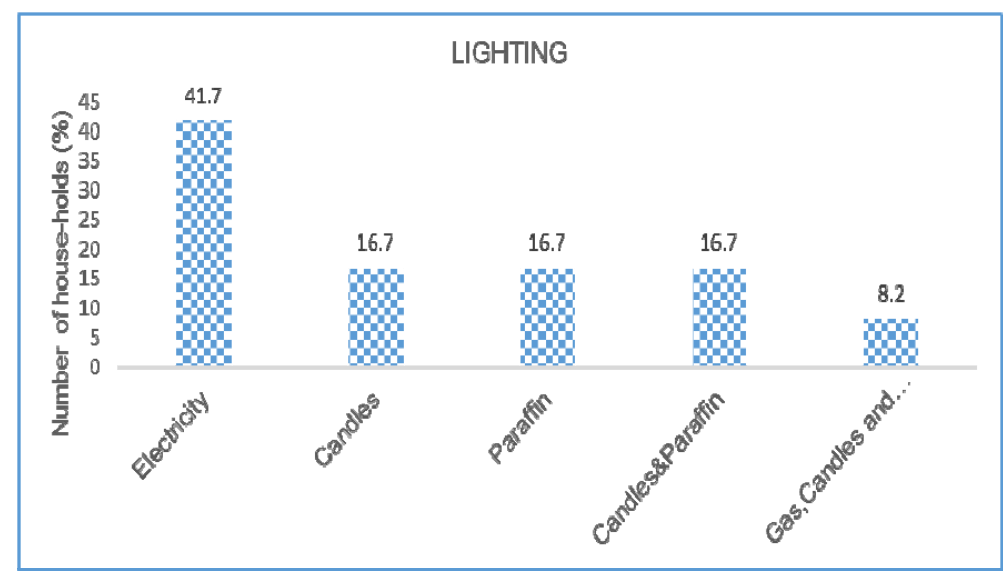

Figure 2: Energy usage in percentage for lighting purposes.

In terms of lighting, households that have been electrified almost exclusively use electricity for lighting purposes (41.7\%), with a marginal contingent specifying that they continue to rely on candles (16.7 \%). By contrast, non-electrified households rely on candles and paraffin (16.7\%) as their main source of lighting, Other energy sources hardly feature, and no single option is mentioned in more than $8 \%$ of cases.

Figure 3, shows a bar graph in percentage of the energy used by the Melani households for cooking purposes. 


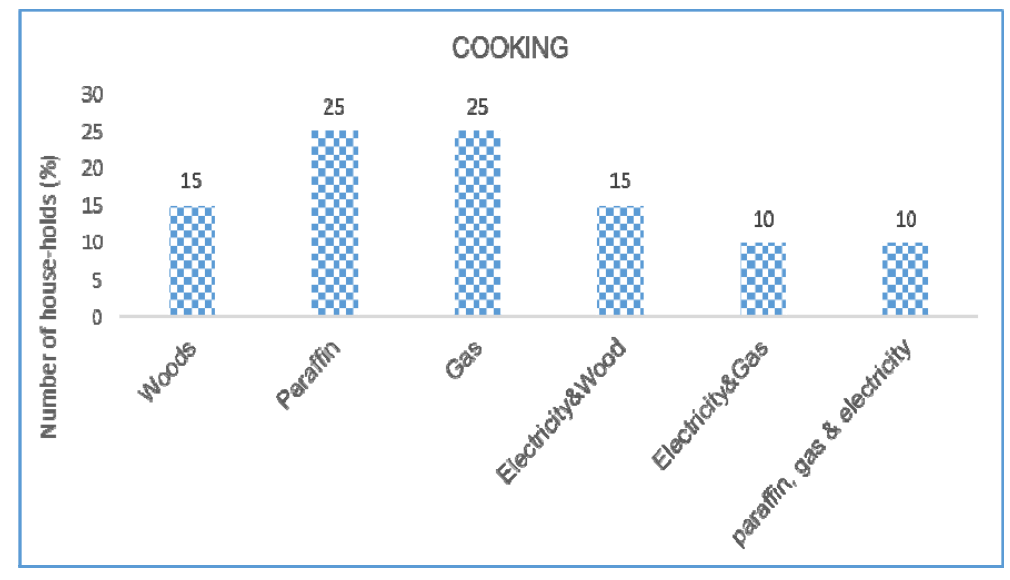

Figure 3: Energy usage in percentage for cooking purposes.

Cooking represents one of the most energy-intensive applications [8] and, as such, it is unsurprising that slightly more than three-quarters (76\%) of households use electricity as the main energy source for cooking [1].

Research has shown that the usage of electricity for cooking has been increasing, but at a slower rate than for lighting and media uses [4]. A complex set of factors is said to govern the decision not to adopt electricity for thermal applications once a household has been electrified, ranging from cultural inertia to change to the perceived lack of affordability of electricity [4][5]. Nonetheless, the 2011/12 statistics show that only around a tenth (8\%) of electrified households continue to depend on firewood as a main cooking source, with marginal shares reporting gas, solar electricity, paraffin and coal. For non-electrified households, firewood and paraffin predominate as the main energy source for cooking purposes. Figure 4.3, shows a bar graph in percentage of Melani households that are using various energy sources for cooking and lighting.

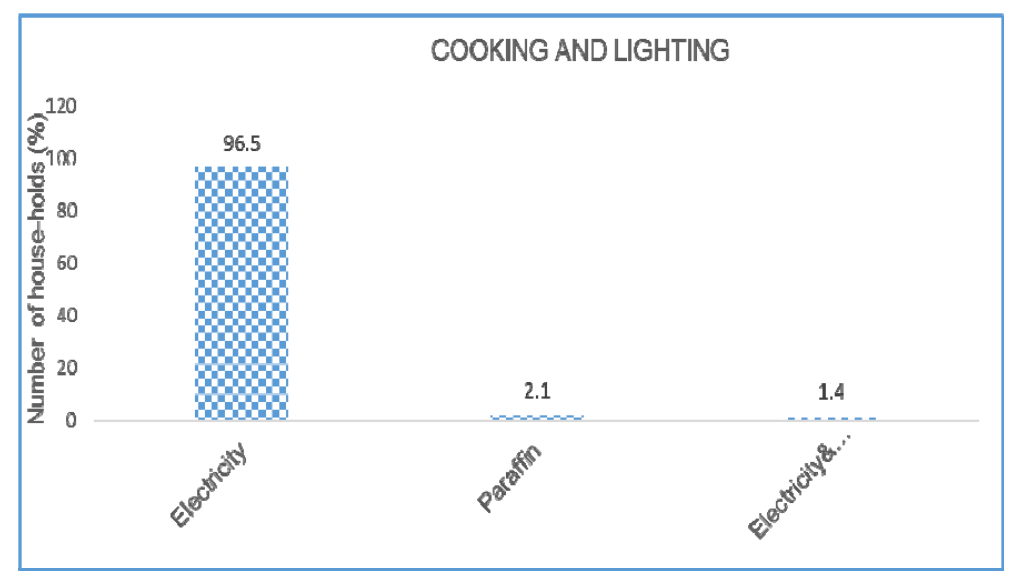

Figure 4: Energies used for cooking and lighting

Households that have been electrified almost exclusively use electricity for lighting and cooking purposes (96.5\%), with a small number of households depending on paraffin (2.1\%) and very few households depending on the combination of electricity, gas and paraffin (14\%) as the source of energy for cooking and lighting.

Meanwhile, the non-electrified households depend mainly on fire woods, gas and paraffin as their main sources of energy for cooking purposes.

\section{B. Data Acquisition System Results}

Figure 5 is showing the average electricity consumption by the Melani households. The figure is showing a seven days (from Sunday to Saturday) of electricity consumption patterns. 


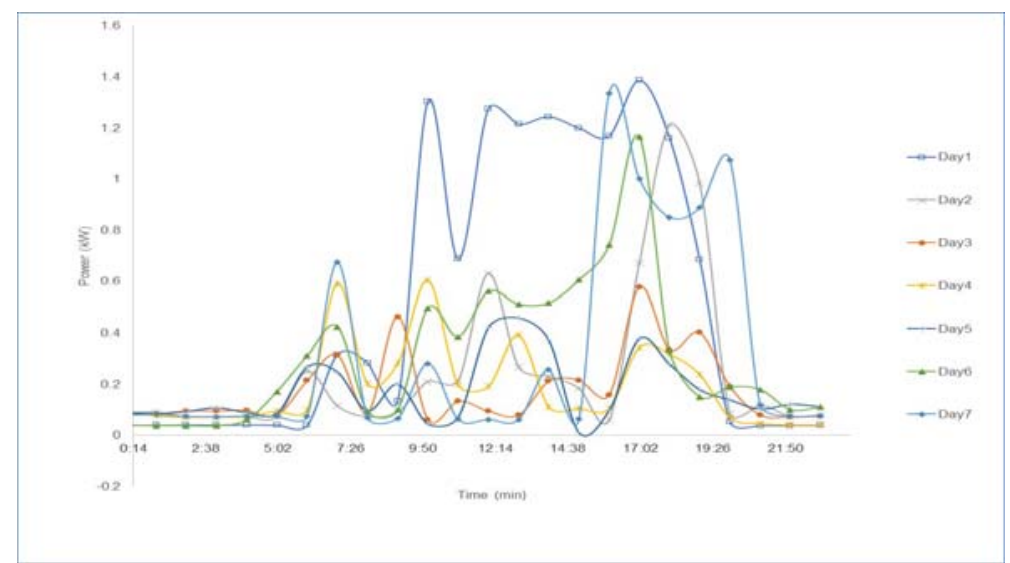

Figure 5: A typical week of electricity consumption

The active power consumption of the house-hold was equivalent to the product of the AC current and the voltage and is given by:

$$
P=I V
$$

Where, $\mathrm{P}=$ Average power consumption in $\mathrm{kW}$

$$
\begin{aligned}
\mathrm{I} & =\text { Average measured AC current in A } \\
\mathrm{V} & =\text { Voltage in } \mathrm{V}
\end{aligned}
$$

The daily energy consumed by the main facility and the combine utilities was calculated from the product of the average daily power and time (24 hours). The energy consumed in $\mathrm{kWh}$ is given in the Equation

$E=P t$

Where

$$
\begin{aligned}
& \mathrm{E}=\text { Energy consumed in } \mathrm{kWh} \\
& \mathrm{P}=\text { Power consumed in } \mathrm{kW} \\
& \mathrm{t}=\text { Time in hours }
\end{aligned}
$$

Figure 6, shows a typical day of electricity consumption by the house-hold of Melani village.

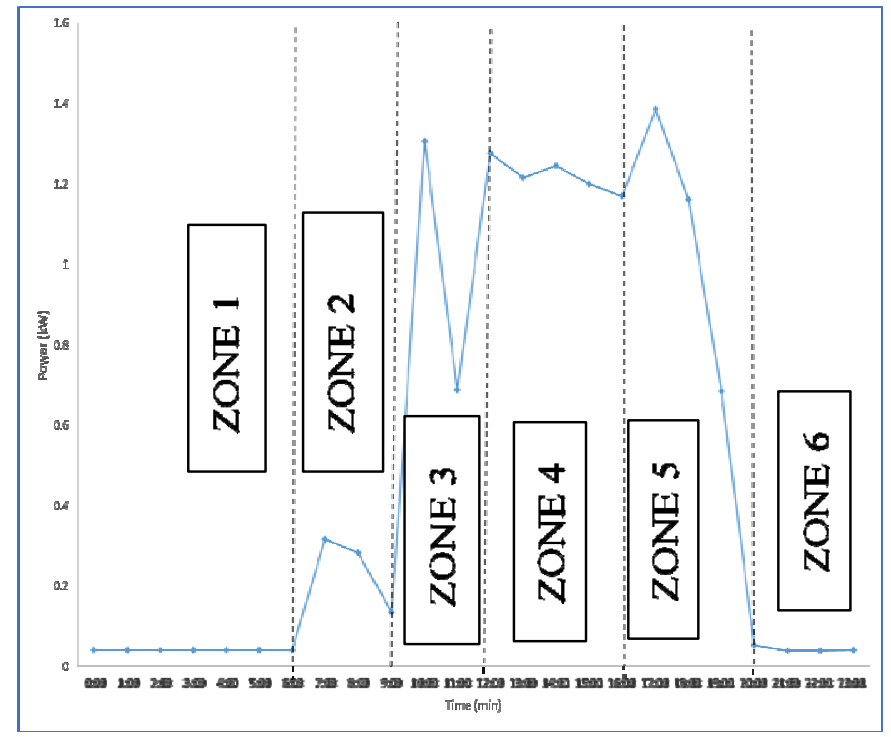

Figure 6: A typical day of electricity consumption

Zone 1

Figure 6 shows that there are no much activities that are taking place, because the electricity consumption is constantly below $0.2 \mathrm{~kW}$. It is constant because the only electrical appliances that are on are the television and two energy saving light bulbs (the front and back of the house). 


\section{Zone 2}

Figure 6 shows that during this time zone the members of the house hold are waking up so as to prepare for activities like church and the breakfast. During this time zone it can be observed that the electricity used has increase to above $0.2 \mathrm{~kW}$ and at around $7 \mathrm{AM}$ it has decreased to below $0.2 \mathrm{~kW}$. The decrease is caused by switching the outside lights and the inside lights. The only switched on electrical appliances are the fridge, television, kettle, stove and the radio

\section{Zone 3}

Figure 6 is shows that there is an increase in electricity usage and this is contributed to by the fact that other members of the household are preparing to go to activities like church and preparing the breakfast for the morning. Hence it can be observed that electricity usage has increase from below $0.2 \mathrm{~kW}$ to above $1.2 \mathrm{kw}$ and sharply decease to above $0.6 \mathrm{~kW}$ after $10 \mathrm{AM}$ since the members of the house hold have gone to church. The increase is contributed to the fact that the remaining house hold members remaining behind are cooking lunch.

Zone 4

Figure 6 shows that at this time the house hold members are back from the activities like church and they are preparing supper and probably watching the television.

Zone 5

At this time zone figure 6 is shows that the household are preparing for the next day, by ironing clothes and by bathing the kids. While this is taking place, television set is on and lights inside and outside the houses are switched on.

Zone 6

During this time zone figure 6 shows that the house hold members are resting and the only electrical appliances that are on are outside lights and the fridge.

\section{DISCUSSION AND CONCLUSION}

Observing at household energy sources, it is evident that considerable arrays of difference exist between electrified and non-electrified households in the range of energy sources that they employ to meet their basic needs. Those with electricity all reported that they used this source either for lighting, cooking or heating, nevertheless it is apparent that other sources such as candles, paraffin, firewood and gas continue to be relied upon in Melani village. Conversely, in the absence of a domestic connection, non-electrified households rely primarily on candles, paraffin and firewood, with more nominal shares reporting the use of coal and gas. The use of dry cell and car batteries, a solar system, or generator hardly features for electrified and non-electrified households.

The paper has shown that Most electrified households use the electricity as their main source of energy for either cooking and lighting. However, the challenge remains the affordability of electricity since most of the bread winners are either elderly or works in farms and earn less than R1000.

\section{ACKNOWLEDGMENT}

I would like to acknowledge the Melani house-hold for allowing us to study the pattern of energy usage in their home. I would like to also greatly acknowledge Dr P Mukumba and Professor S Mamphweli for their contribution in the development of this paper and finally would like to acknowledge CSIR for their financial support.

\section{REFERENCES}

[1] Thompson B, A survey of energy-related behavior and perceptions in South Africa. The Residential sector 2012.

[2] Peters D, A survey of energy-related behaviour and perceptions in South Africa. The Residential sector 2012.

[3] Josephine Kaviti Musango, 2014. Household electricity access and consumption behaviour in an urban environment: The case of Gauteng in South Africa.

[4] Bekker, B., Eberhard, A., Gaunt, T. and Marquard, M. 2008. South Africa’s Rapid Electrification Programme: Policy, Institutional, Planning, Financing and Technical Innovations. Energy Policy, 36 (2008): 3125-3137.

[5] Prasad, G. and Visagie E. (2005) Renewable energy technologies for poverty alleviation Initial assessment report: South Africa, Energy Research Centre, and University of Cape Town South Africa.

[6] Sebitosi A. B., Pillay P., “Energy Services in Sub-Saharan Africa: How conducive is the environment?” Elsevier Energy Policy, Volume 33, Issue 16, November 2005, Pages 2044-2051.

[7] Nkonkobe municipality Intergraded development plan 2015/2016. Accessed September 2016

[8] Howells, M., Victor, D. G., Gaunt, T., Elias, R. J., \& Alfstad, T. (2006). Beyond free electricity: The costs of electric cooking in poor households and a market-friendly alternative. Energy Policy, 34, 3351-3358.

[9] South African Social Attitudes Survey, 2011/2012. Accessed march 2016.

[10] Community Electricity in Rural South Africa: Renewable mini-grid assessment, 2013

[11] DME (Department of Minerals and Energy) (2009) Annual report. 


\section{AUTHOR PROFILE}

Mr. Thabiso Mthimunye is a master's student at the University of Fort Hare in the physics department. He possesses a BSc (Hons) in physics with the University of Fort Hare and a Bachelor of education degree from the University of Fort Hare.

Professor Sampson Mamphweli is a Professor at the University of Fort Hare, Institute of Technology. He possesses a Doctor of Philosophy degree in Physics from the University of Fort Hare, South Africa, a Master of Environmental Sciences degree from the University of Venda, South Africa. He is also in possession of a Certificate in Financing Renewable Energy and Energy Efficiency from RENAC Renewables based in Germany. $\mathrm{He}$ also possesses the Green Power Mini-MBA from the Green Power Academy based in Britain. He is a recipient of the prestigious University of Fort Hare Vice Chancellor's Emerging Researcher medal for the year 2012. He conducts research on renewable energy technologies and their applications, and he is a respected authority in the biomass to energy field. He has published up to 18 scientific papers in peer-reviewed journals and conference proceedings including two book chapters. In addition, he reviews papers for publication in several journals in the engineering and renewable energy fields of study. His current area of research interest includes biomass gasification for electricity generation, biogas digesters, co-gasification of coal and biomass for electricity generation as well as solar energy.

Dr. Patrick Mukumba is a lecturer and Researcher in Physics Department at the University of Fort Hare (UFH). He possesses a Doctor of Philosophy degree in Physics from the University of Fort Hare, South Africa, MSc in Renewable Energy Engineering from the University of Zimbabwe, a BSc Ed (Hons) in Physics with Bindura University of Science Education (Zimbabwe) and a Diploma in Education (Science) with Belvedere Technical Teachers' College (Zimbabwe). He specialized in Renewable Energy Engineering, encompassing Biomass and Biogas, Wind Energy, Photovoltaics, Solar Thermal Collectors and Hydropower plants. He has published up to 13 research papers in peer-reviewed journals and conference proceedings including two book chapters. Finally, he is a reviewer for Renewable and Sustainable Energy Reviews journal and Journal of Engineering Design and Technology (South Africa). 